\title{
Analysis of Substitute Products in the Demand for
}

\section{Food Products in Côte D'Ivoire}

\author{
Tite Beke \\ Félix Houphouët Boigny University of Cocody - Abidjan/CIRES \\ 01 BP V 43 Abidjan - Côte d'Ivoire, Email: beketite@yahoo.fr
}

Received: June 15, 2017

Accepted: July 4, 2017 Published: October 30, 2017

doi:10.5296/jas.v5i4.11402

URL: https://doi.org/10.5296/jas.v5i4.11402

\begin{abstract}
This study analyzes the demand for staple foods in Côte d'Ivoire and assesses the impact of fluctuations in food prices on household well-being. It focuses on the priceand income elasticities of food demand, as they are useful parameters for measuring households' reaction to the changes in prices and incomes, and for improving food policies. The study also assesses the loss in well-being arising from food crises with a view to recommending more effective measures for supporting households. It uses an approach that estimates a Quadratic Almost Ideal Demand System (QUAIDS) in order to highlight price and expenditure elasticities. The data used in the study were obtained from the National Household Living Standards Survey (ENV) conducted by the National Institute of Statistics (INS) in 2008. The estimated expenditure- and price elasticities show that the four food clusters under analysis (cereals, root crops and tubers, fruit and vegetables, and animal products) were staple foods that were price inelastic for all the households. A substitutability relationship is observed between cereals, and root crops and tubers. However, animal products and vegetables are found to be complementary to each other and complementary to cereals and root crops and tubers.
\end{abstract}

Keywords: Food security, demand system, analysis of well-being

JEL: D12; Q18; C30.

\section{Introduction}

Food and nutritional security is one of the eight United Nations Millennium Development Goals (MDGs), and one of the most important goals for developing countries. Close to 800 million people in developing countries, that is $20 \%$ of their entire populations, are undernourished (according to the United Nations Millennium Project, 2005). According to the Food and Agricultural Organizations of the United Nations (FAO), sub-Saharan Africa has the highest rate of undernourished people in the world (FAOSTAT, 2010).

The FAO's projections indicated that it was unlikely that the MDG related to food, namely reducing the number of undernourished people by half, would be achieved by the end of 2015. Côte d'Ivoire is among the developing countries that are still far away from halving the number of people suffering from hunger. According to the country's 
National Bureau of Technical and Development Studies (BNETD), Côte d'Ivoire's annual population growth rate is $3.3 \%$, while its food availability rate increases by only $3 \%$ a year, meaning that it cannot meet all its food needs commensurate with its population growth (BNETD, 2010).

A survey conducted by the FAO and the WFP in 2008 showed that $17 \%$ of Côte d'Ivoire's population was undernourished, while the food needs for $20 \%$ to $40 \%$ of its households were not met (FAO and WFP, 2008). This means that the vulnerable groups in the country suffered even more from such a food shortage, given the disparities between social groups.

A greater understanding of the manner in which the demand for food commodities varies according to the different income groups and changes according to price fluctuations is essential for the country to put in place concrete measures for food security in order to get closer to achieving the first MDG.

The variation in the relative prices between imported staple foods (notably rice and meat), of which prices rose considerably following the food crisis of 2007/2008 and the other food commodities, of which prices remained relatively stable, has most likely changed the structure of household food expenditures. Estimations of price elasticities will enable the present study to determine which food substitutes were taken up and to measure the well-being variation that occurred as a result of price changes.

Without a deep understanding of the manner in which food expenditures vary according to income and regions, it will be difficult to devise policies capable of improving food security in an effective way for sets of heterogeneous households. That is why the present study takes into account regional differences and income differences in dietary preferences so as to enable a better understanding of food expenditure patterns in Côte d'Ivoire.

The study will produce a complete matrix of price and expenditure elasticities of the demand for nine main food commodities (rice, maize, wheat, yam, cassava, plantain, fruit and vegetables, fish, and meat) by income group. These elasticities measure the variation, in percentage, in food expenditures arising from changes in budgets and prices. The loss in well-being associated with the rise in prices will also be measured from the estimated parameters of the demand functions.

\section{Objectives of the Study}

The aim of this study is to analyze the demand for staple foods in Côte d'Ivoire and to assess the impact of price fluctuations on household well-being. Its specific objectives are to:

i. estimate a demand system for foodstuffs;

ii. measure, by income group, the household demand response to the variations in incomes and prices; and

iii. measure the impact of price variations on household well-being.

\section{Justification for the Study}

An analysis of the demand for food products in developing countries has attracted increasing interest over several decades. Since it is well acknowledged that income influences the food expenditure structure, it is very likely that income distribution will also influence food expenditure distribution. Studies that examine the food expenditure structure in relation to income will thus be of great interest to decision-makers wishing to implement targeted food policies. 
The non-availability of data of a microeconomic nature has been a limitation to most of the previous studies on food demand in developing countries (Taljaard et al., 2004; Nieuwoudt, 1998). The nationally aggregated data that are usually used in such studies do not enable one to take into account demographic factors that are specific to households (Abdulai, 2002). Yet such factors can be relevant to the analysis of the demand for foodstuffs.

The present study uses data collected from households by the National Institute of Statistics (INS) in 2008, which was conducted to gather information on households' food consumption behaviour in Côte d'Ivoire. It uses the quadratic Almost Ideal Demand System (QUAIDS), which has been recently put forward by Banks, Blundell and Lewbell (1996) for the specification of a demand system that includes demographic effects. This quadratic specification enables the price and expenditure elasticities to vary according to the level of income.

The useful properties of the quadratic specification explain the fact that it has been used in a number of studies. Applications of this model to cross-sectional data have been made by Banks et al. (1996), Blundell and Robin (2000), Lyssiotou (2003), Nicol (2003), Unayama (2004), and Dhar and Foltz (2005), while applications of it to time series have been made by Jones and Mazzi (1996), Fisher et al. (2001) and Karagiannis and Velentzas (2004). In most of these applications, the words "quadratic demand system" appear to be key to the explanation of consumer behaviour.

The application of this model to the analysis of the demand for foodstuffs in Côte d'Ivoire is of great interest, to the extent that quite a few studies have tackled this issue by taking adequate account of the differences in the levels of household incomes. Indeed, given the fact that low-income households and high-income ones respond differently to changes in prices and incomes, it is useful to estimate a demand model whose functional form allows income and price elasticities to vary with income. The present study divided the sample into three income groups in order to examine each group's response to price and expenditure variations.

\section{Literature Review}

\subsection{Theoretical Literature}

Three demand systems have received considerable attention thanks to their empirical usefulness. These are: the Linear Expenditure System (LES), developed by Stone (1954); the Almost Ideal Demand System (AIDS), developed by Deaton \& Muellbauer (1980); and a combination of these two systems into a Generalized Almost Ideal Demand System (GAIDS), put forward by Bollino (1990). Other demand systems found in the literature, but not as widely used as the former three, are the Rotterdam model of Theil (1976), the Transcendental Logarithmic (Translog) model of Christensen, Jorgenson \& Lau (1975) and, more recently, the Quadratic Almost Ideal Demand System (QUAIDS) of Banks et al. (1996).

The aim of this section is to highlight the functional forms of these demand functions. The LES and AIDS models, which have been very popular and widely used in empirical studies, are discussed in the section.

It is a property of Stone's Linear Expenditure System (LES) that the general restrictions of the classical theory of demand are entirely imposed on each set of data. Only this type of demand system has this property. Stone's LES can be obtained from the Stone-Geary utility function, which is a separable function. It has the following form: $\left(x_{i}\right)=\sum_{i=1}^{n} \beta_{i} \ln \left(x_{i}-\gamma_{i}\right)$, where $\beta_{i}$ and $\gamma_{i}$ are parameters. An important disadvantage of this system is that it involves linear Engel curves. Like all separable 
demand functions, the LES model is more applicable to large categories of expenditure than to specific goods, since the model does not allow for inferior goods; it assumes that all goods are complementary. Estimating the linear demand systems is difficult because of the non-linearity of their coefficients, which enter into the demand equations in a multiplying way.

To overcome this limitation, the AIDS models have often been used. An AIDS model is based on a utility function specified as a second-order specification of whatever utility function. Demand functions are obtained in a budget share form. The functional form of the AIDS model enables an easy estimation of price elasticities and income elasticities. However, it does not allow these elasticities to vary with the level of income.

It is a well-known empirical fact that the expenditure allocated to different categories of goods varies non-linearly with the size of the budget (one example in relation to food expenditure is Engel's law). That is why more and more recent studies have suggested the need for a quadratic specification in relation to income (see, for example, Atkinson et al., 1990; Blundell et al. 1993, and Hausman et al., 1994).

The QUAIDS model, which was derived from the problem of utility maximization posed by Banks et al. (1996), not only preserves the desirable properties of the Almost Ideal Demand System (AIDS) of Deaton \& Muellbauer (1980), but also has the advantage of being more flexible in modelling the consumer's expenses. In particular, the QUAIDS model enables a situation where a luxury good becomes, for the consumer, a normal good when his/her income increases.

\subsection{Empirical Literature on the Demand for Foodstuffs in Developing Countries}

Several empirical studies on the demand for foodstuffs have focused on developing countries. Among them is one by Senauer \& Kinsey (1991), which demonstrated that households in developing countries could allocate between $60 \%$ and $89 \%$ of their income to food expenditure. Between $40 \%$ and $60 \%$ of this expenditure could be allocated to just one food item.

The AIDS model of Deaton \& Muellbauer (1980) has been popular and widely used to analyze household demand for the last two decades. Significant empirical results were obtained by using the AIDS model (Senauer, 1990; Timmer, 1981). Senauer (1990) reported that the demand for rice was more sensitive to income and price variations for low-income households in developing countries. Timmer (1981), who analyzed the demand for foodstuffs in Indonesia, found similar results for rice and cassava.

Empirical studies on microeconomic data, notably those by Lewbel (1991) and Banks et al. (1996), have shown that the AIDS model has limitations in terms of correctly describing household behaviour when there are high levels of income inequality. That is why, for a better analysis of households' food demand behaviour in Peru, a specification test was conducted by Molina \& Gil (2005) to determine which of the linear (AIDS) or quadratic (QUAIDS) specifications was more appropriate. A demand system was estimated afterwards for six aggregated consumer goods (food, health, transport, leisure, tobacco, and miscellaneous products) using cross-sectional survey data. The results first indicated that the AIDS model had been rejected in favour of a QUAIDS one. Further, the income elasticities revealed that transport and leisure were luxury goods, while tobacco and health-related goods and services were necessary goods.

In Africa, most studies on food demand have been based on highly aggregated (macroeconomic) data. In general, these studies have limited themselves to examining a single food commodity (Taljaard et al., 2004; Nieuwoudt, 1998) or they have ignored the effect of demographic factors on food demand (Liebenberg \& Groenewald, 1997). 
Unlike previous research, the studies conducted by Agbola (2002) and Bopape \& Myers (2007) were based on microeconomic data. Agbola (2002) determined a complete demand system for households in South Africa based on microeconomic data. The AIDS model, which he used, is, however, restrictive and does not enable an appropriate representation of the flexibility of an Engel curve.

In a related study, using panel data on household food consumption in South Africa, Bopape \& Myers (2007) explicitly tested the specification of the demand model and confirmed the relevance of the quadratic specification. Their model took into account structural changes and seasonal effects. The results of their estimations showed that the demand for cereals was inelastic to income variations for all the income groups. Even though meat and fish were found to be luxury goods, the income elasticity of the demand for them was found to be higher in rural households (typically low-income households) than in urban households (typically, high-income ones).

In the present study, an analysis of the demand for food is done using a QUAIDS model that takes into account sociodemographic factors.

\section{Methodology}

\subsection{The Theoretical Framework}

\section{A microeconomic model}

Let $p=\left(p_{1}, \ldots, p_{n}\right)$ be the vector of nominal prices for $n \operatorname{good}$ and $R$ the amount of total expenditure allocated to these goods by the consumer.

Consider the following indirect utility function:

$$
\ln (V(p, R))=\left\{\left[\frac{\ln (R)-\ln (a(p))}{b(p)}\right]^{-1}+\lambda(p)\right\}^{-1}
$$

where $\ln$ is the natural logarithm and $a(p), b(p)$ and $\lambda(p)$ are different price aggregation functions defined as follows:

$$
\begin{gathered}
\operatorname{lna}(p)=\alpha_{0}+\sum_{i} \alpha_{i} \ln p_{i}+\frac{1}{2} \sum_{i} \sum_{j} \gamma_{i j} \ln p_{i} \ln p_{j} \\
b(p)=\prod_{i=1}^{n} p_{i}^{\beta_{i}} \\
\lambda(p)=\sum_{i=1} \lambda_{i} \ln p_{i} \text { where } \sum_{i=1}^{n} \lambda_{i}=0
\end{gathered}
$$

$a(p)$ is a homogeneous function of degree 1 while $b(p)$ and $\lambda(p)$ are homogeneous functions of degree 0 in $p$, such that $V(p, R)$ is a homogeneous function of degree 0 in $p$ and $R$, as required. It is assumed that the parameters meet the following restrictions: $\quad \sum_{i} \alpha_{i}=1 ; \sum_{i} \beta_{i}=0 ; \sum_{i} \gamma_{i j}=0 ; \sum_{i} \lambda_{i}=0 ; i, j=1, \ldots n \quad, \quad$ which guarantee the theoretical conditions of aggregation and homogeneity.

By applying the logarithmic form of Roy's identity

$\left[W_{i}=-\left(\partial \ln V / \partial \ln p_{i}\right) /(\partial \ln V / \partial \ln R)\right]$ to Equation 1, one gets the quadratic almost ideal demand function specified as follows: 


$$
w_{i}=\alpha_{i}+\sum_{j} \gamma_{i j} \operatorname{lnp}_{j}+\beta_{i} \ln \left(\frac{R}{a(P)}\right)+\frac{\lambda_{i}}{b(P)}\left[\ln \left(\frac{R}{a(P)}\right)\right]^{2} \quad i=1, \ldots n
$$

where $w_{i}$ designates, for each individual, the share of the expenditure allocated to good $i$.

The income and price elasticities for the QUAIDS model are derived from Equation 5. Since these elasticities are linear in $\ln (R)$, they vary with income. Unlike the AIDS model in which the elasticities are independent of income, the QUAIDS one enables us to account for the effects related to income changes.

\subsection{Forming Goods Clusters and Building the Test of the Separability of Preferences}

Forming goods clusters

In theory, demand systems make the demand for a given good dependent upon its own price, the price of all the other goods and the household's income. However, in practice it is not possible, due to lack of data and for econometric reasons, to take into account the effects of all the goods for which there is a demand from households (Allen, 2010).

The literature on demand has proposed two approaches that allow for an aggregation of goods in a manner that facilitates empirical analysis. The first approach, which rests on the Composite Commodity Theorem (CCT) initially proposed by Hicks and Leontief, consists of forming homogeneous clusters of goods based on their prices.

The CCT hypothesizes that if prices within a cluster of goods fluctuate in a parallel way, then the underlying cluster can be assimilated to a homogeneous set in terms of preferences and can be considered one and the same good. In practice, the CCT is too restrictive to be used in empirical studies. This is because there is too much variability in relative prices to allow the CCT hypothesis to hold (Deaton \& Muellbauer, 1980).

By way of an alternative to the CCT hypothesis, the literature has proposed, in order to reduce the number of goods, the separability of preferences. According to the separability-of-preferences assumption, the distribution of expenditures within a cluster of goods is done independently of the consumer's behaviour vis-à-vis the other goods. More specifically, the assumption rests on a process of budgeting in stages. It is assumed that initially the consumer shares out his/her total budget among the major clusters of goods, then he/she later allocates the expenditure within each cluster.

Those assumptions about the form of consumer preferences can be represented by a utility tree. Products are divided into groups in such a way that the preferences within a given cluster can be defined independently of the choices made in other groups.

The present study has adopted an approach that has been widely used and that consists of assuming the separability of preferences between food and non-food goods (Allais et al., 2010. This is a necessary and sufficient assumption for a sequential allocation of total expenditure in three steps. In the present case, it enables the consumer to envisage a first budgeting stage at which he/she will decide to share out his/her income between food and non-food products. Another two budgeting stages are later envisaged between the food clusters formed according to the nomenclature used by the National Institute of Statistics (see Figure 1).

The forming of food clusters was aimed at reconciling the two-fold goal of creating homogeneous groups in terms of their nutritional and energy intake. The first aspect to this goal is the need to conform to the food nomenclature used by the National Institute of Statistics and derived from the international COICOP nomenclature structured in a nested way in functions, clusters, sub-clusters, posts, varieties and series. The second 
aspect is directly related to the present study's research question: it consists of identifying the possible complementarity and substitution relationships between the staple food products that are likely to be the focus of special attention in the development of national food security policies. It is thus important to highlight, within each food cluster, the products that dominate household consumption.

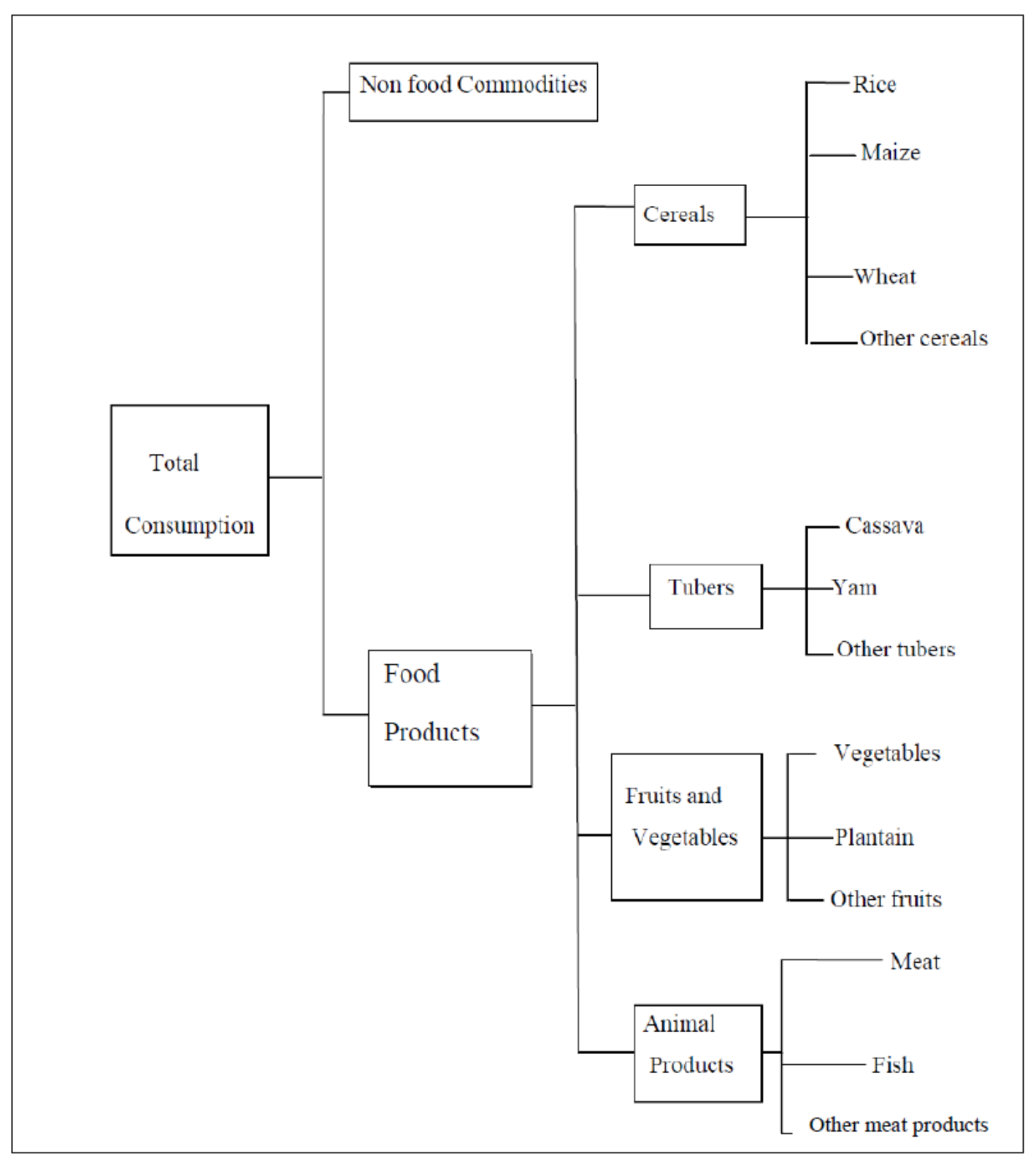

Source: Author

Figure 1: Diagram of a three-stage budgeting process for food demand

Finally, as Figure 1 above indicates, we get nine specific staple foods grouped into four major homogeneous classes in terms of their nutritional and energy intake (cereals, tubers, fruit and vegetables, and animal products).

The test of the separability of preferences

A number of authors have suggested that the assumption of separability of preferences should be empirically tested (Moschini et al., 1994; Nayga \& Capps, 1994; Carpentier \& Guyomard, 2001; Jones and Mazzi, 1996). Following Moschini et al. (1994), the 
present study used a likelihood ratio test to verify the assumption of separability between the four food clusters, namely cereals, tubers, fruit and vegetables, and animal products. The test was done by comparing the reduced demand model, which excludes any complementarity or substitution relationship between two different groups and the unreduced demand model. The test's null hypothesis says that the substitution or complementarity elasticities between the food products in the different clusters are all equal to zero.

The statistic for the likelihood ratio (chi $2(6)=310.34$ ) led the present study to reject the null hypothesis of separability of preferences. The implication of this result is that the demand for foodstuffs within a given cluster is affected by the changes in the prices of the foodstuffs in the other clusters. Because of this, the study estimated both a between-group demand system and a complete demand system for the different foodstuffs.

Table 1. The separability test at the second stage of budgeting

$$
\begin{aligned}
& \text { SUR (unrestricted) } \\
& w_{i}=\alpha_{i}+\beta_{1} \log (m)+\beta_{2}(\log (m))^{2}+\sum_{j} \gamma_{i j} \log \left(p_{j}\right) \quad i, j=1,2,3,4 \\
& \text { SUR (restricted) } \\
& w_{i}=\alpha_{i}+\beta_{1} \log (m)+\beta_{2}(\log (m))^{2}+\gamma_{i} \log \left(p_{i}\right) ; \gamma_{i j}=0 \forall i \neq j \\
& \text { LR Statistic (LR 310.34 } \\
& \text { chi2(6)) } \\
& \text { P-value (Prob > chi2) } \\
& 0.0000
\end{aligned}
$$

Source: Author's computations based on the 2008 ENV survey; SDs in parentheses; ${ }^{* * * * * *},{ }^{* *}$ : significant at $1 \%, 5 \%$ and $10 \%$

\subsection{Empirical Specification of the Demand Models}

The present study's relatively detailed grouping of food clusters into main products enabled it to estimate a demand model with two levels: a between-group demand system and a disaggregated demand system.

\section{Specification of the between-group demand system}

The expenditure shares allocated to the different food clusters are described as follows:

$W_{1}=$ cereals; $W_{2}=$ tubers; $W_{3}=$ fruit and vegetables; $W_{4}=$ animal products

Below is the specification:

$$
W_{k}=\alpha_{k}+\sum_{l} \gamma_{k l} \ln p_{l}+\beta_{k} \ln \left(\frac{R}{a(p)}\right)+\frac{\lambda_{k}}{b(p)}\left[\ln \left(\frac{R}{a(p)}\right)\right]^{2}+\sum_{s=1}^{M} \delta_{s} z_{s}, \quad k, l=1,2,3,4 .
$$

$k, l=$ food clusters;

$W_{k}=$ the expenditure share allocated to group $\mathrm{k}$;

$p_{l}=$ the weighted average for the prices of the food products in cluster $l$;

$R=$ the total food expenditures; while $z_{s}$, where $s=1, \ldots, M$, represents demographic variables.

\section{Specification of the complete demand system for the main foodstuffs}


$W_{i}=\alpha_{i}+\sum_{j} \gamma_{i j} \ln p_{j}+\beta_{i} \ln \left(\frac{R}{a(p)}\right)+\frac{\lambda_{i}}{b(p)}\left[\ln \left(\frac{R}{a(p)}\right)\right]^{2}+\sum_{s=1}^{M} \delta_{s} z_{s}$

$i, j=$ rice, maize, wheat, yam, cassava, plantain, vegetables, meat and fish

$W_{i}$ is the expenditure share allocated to product $i$ of the nine staple foods;

$p_{j}$ is the price of product $j$;

$R$ is the total food expenditures; and $Z=\left(z_{1}, \ldots, z_{M}\right)$ is a vector of the demographic variables.

\subsection{Analysis of Well-being}

Measuring the well-being of economic agents has always been a major concern for economists and policy-makers. It is also the aim of the present study to measure, in monetary terms, the impact of price changes on household well-being. The study used two key measures of well-being: the compensating variation ( $V C$ in the equation below) and the equivalent variation in income ( $E V$ in the equation below) (Urzùa, 2001).

The compensating variation ${ }^{1}$ gives the monetary sum it would be appropriate to give to (or take away from) the consumer to compensate for a possible increase (or drop) in prices:

$$
V\left(P_{0}, R_{0}\right)=V\left(P_{1}, R_{0}+V C\right)
$$

where $V($.$) is the indirect utility function, P_{0}$ the old price system, $P_{1}$, the new price system, and $R_{0}$ the consumer's initial income.

The present study chose to measure the compensating variation, as is generally the case when the aim is to measure the loss in well-being following an effective rise in prices.

The QUAIDS model used in the present study entailed specifying the Price Independent Generalized Logarithm (PIGLOG). The indirect utility function on which the class of PIGLOG functions rests is expressed as follows:

$$
\ln V(p, R)=\frac{\ln R-\ln a(p)}{b^{\prime}(p)}
$$

where $a(p)$ and $b^{\prime}(p)$ are two price aggregates, functions of the price vector $p$. More specifically, with $\alpha_{i}, \beta_{i}$ and $\gamma_{i j}$ being the parameters of the demand model, we have: $\ln a(p)=\alpha_{0}+\sum_{i=1}^{n} \alpha_{i} \ln p_{i}+\frac{1}{2} \sum_{i=1}^{n} \sum_{j=1}^{n} \gamma_{i j} \ln p_{i} \ln p_{j}$ and $b^{\prime}(p)=\prod_{i=1}^{n} p_{i} \beta_{i}$.

Simplifications enable a specification of the direct expression of the function for the compensating income as follows:

$$
\ln R_{c}=\ln a\left(p_{1}\right)+\prod_{i=1}^{n}\left(\frac{p_{1 i}}{p_{0 i}}\right)^{\beta_{i}}\left(\ln R_{0}-\ln a\left(p_{0}\right)\right)
$$

The compensating variation of the income corresponding to the loss in well-being following a price rise is given by: $V C=R_{c}-R_{0}$.

\footnotetext{
${ }^{1}$ Alternatively, it is possible to measure the loss (or gain) in well-being arising from a rise (or a drop) in prices by the monetary sum which consumers would be ready to pay (or receive) to cushion themselves against price changes; that is, the equivalent variation in income.
} 


\section{Data used in the Study}

The data used in the present study came from the National Household Living Standards Survey (ENV) conducted by the INS in 2008 (INS, 2008). This survey collected a wide range of data on households' socioeconomic characteristics, including their expenditures on food and non-food products and their prices. Of particular relevance to the present study is the disaggregated data on households' food expenditures. The survey also collected information about the same households' geodemographic characteristics. It used a sample of 12,000 households drawn from all over the country (see Table 2).

\subsection{How Aberrant and Missing Values were Dealt with}

\section{The missing values}

The missing values were dealt with in different ways, depending on whether the household's expenditure and/or quantities consumed had been observed or not. Where both the quantities consumed and the expenses appeared simultaneously missing or null on the same line, the observation was dropped from the sample. But where only one of the two was missing, the non-reported value was extrapolated from the regional prices.

The study reports the observed expenditures at regional prices in order to extrapolate the non-reported quantities consumed. However, when the missing data concern some expenditure, the latter is deduced by calculating the product of regional prices and the observed quantities consumed.

\section{The aberrant values}

The aberrant values were detected by studying the distribution of expenditures and quantities in the sample used. To study the distribution, the usual statistical tests for compatibility with the log-normal or normal distribution are the Shapiro-Wilk and Francia-Shapiro tests, and those based on asymmetry and kurtosis coefficients (Royston, 1983).

Although very popular, the Shapiro-Wilk and the Francia-Shapiro tests can only be used with a sample limited to fewer than 2,000 and 5,000 observations, respectively. With the sample in the present study being 12,000 households, the alternative was the tests based on asymmetry and kurtosis coefficients. However, these tests are very much influenced by the size of the sample. Indeed, compatibility with the normal law is often the rule in the case of small samples. On the other hand, incompatibility with the normal law is almost systematically determined on the basis of big samples, even when the distribution differences are small. Because of this, empirical approaches, especially graphic ones, are still very relevant. The present study used the box-plot.

The box-plot is a very practical graphic tool representing an empirical distribution with the help of some localization parameters: the median, the first quartile and the third quartile. Using it enables one to detect the outliers situated outside the extremities delimited by 1.5 times the interquartile range. In total, $18 \%$ of the observations made in the present study were deleted. Table 2 gives the percentages of the observations that were deleted by region.

Table 2: Percentages of deleted observations and number of valid observations

\begin{tabular}{lccccccc}
\hline Regions & Abidjan & North & East & Centre & West & South & Total \\
\hline No. of households surveyed & 2,200 & 1,289 & 1,289 & 3,111 & 2,178 & 1,933 & 12,000 \\
\% of deleted observations & 19 & 17.46 & 17.84 & 17.81 & 18.5 & 18.26 & 18.19 \\
No. of valid observations & $\mathbf{1 , 7 8 2}$ & $\mathbf{1 , 0 6 4}$ & $\mathbf{1 , 0 5 9}$ & $\mathbf{2 , 5 5 7}$ & $\mathbf{1 , 7 7 5}$ & $\mathbf{1 , 5 8 0}$ & $\mathbf{9 , 8 1 7}$ \\
\hline
\end{tabular}

Source: Compiled by the author on the basis of data from the 2008 ENV survey 
Households were classified into three income groups according to their annual income: (1) low-income households, composed of those with an annual income lower than CFAF 316,200 (€482) and representing $25 \%$ of the sample; (2) middle-income households, composed of those with an annual income between CFAF 316,200 and $1,216,656(€ 1,854)$ and representing $50 \%$ of the sample; and (3) high-income households, composed of those with an annual income higher than CFAF 1,216,656 (higher than $€ 1,854$ ).

\subsection{Determining the Prices}

The INS has a consumer price index for all the specific food products studied. With regard to prices of clusters of products, it offers a weighted average of the prices of products composing each cluster. In addition, for each product and cluster, it specifies the common prices by region based on regional deflators.

However, differences were observed between unit values (the ratio of household expenditures to the quantities bought) and regional prices. In the literature, such differences have been attributed to quality effects (Cox \& Wohlgenant, 1986; Deaton, 1997; Deaton \& Tarozzi, 2000).

Correction for quality is necessary since the nomenclature at our disposal does not distinguish products according to their quality. In order to take quality effects into account, several correction methods have been proposed (Cox \& Wohlgenant, 1986; Deaton, 1997). Following Cox \& Wohlgenant (1986), the present study did a regression analysis of the unit values on a set of sociodemographic variables that were assumed to determine household choices in terms of quality. It assumed that household socioeconomic characteristics, such as income and level of education, could lead to decisions to buy products of different qualities. The estimated price for a household was determined from the average regional price and the residue of the regression that was supposed to capture the price difference that was not due to quality. In this way, a unit value that was corrected for quality was obtained. The introduction of the random term also allowed the study to introduce a certain variability in prices (Allen, 2010).

\section{Household Sociodemographic Characteristics and Food Expenditure Structure in Côte d'Ivoire}

The 2008 National Household Living Standards Survey (INS, 2008) collected data on a range of household sociodemographic characteristics: household size, age, gender, education level of the head of the household, and area of residence. Household socioeconomic and geodemographic characteristics play an important role in understanding the demand structure. The demand model was estimated by incorporating these control variables so as to take into account the heterogeneity between households. A statistical summary of the socioeconomic and sociodemographic variables is presented in Table 3. 
Table 3: Statistical summary of household socioeconomic and geodemographic characteristics

\begin{tabular}{lccccc}
\hline Variable & \multicolumn{2}{c}{ Area of residence } & Total sample & t-test & P-value \\
\hline & Urban & Rural & & & \\
\% of male heads of household & 84.79 & 87.41 & 86.10 & -6.7869 & 0.0000 \\
Household size & 5.77 & 6.39 & 6.18 & -32.3903 & 0.0000 \\
Age of head of household & 40.22 & 40.62 & 40.54 & -2.9889 & 0.0014 \\
Level of education (\%) & & & & & \\
Without formal education & 49.30 & 58.4 & 53.57 & -15.0605 & 0.0000 \\
Primary education & 15.96 & 18 & 16.91 & -60.1998 & 0.0000 \\
Secondary education & 26.91 & 20.29 & 228 & 68.325 & 0.0000 \\
Higher education & 7.93 & 3.31 & 5.76 & 52.8666 & 0.0000 \\
Region (\%) & & & & & \\
Northern (Region 1) & 18.7 & 22.7 & 20.6 & -6.7959 & 0.0000 \\
Eastern (Region 2) & 17.8 & 21.7 & 19.6 & -6.8651 & 0.0000 \\
Central (Region 3) & 11.9 & 15 & 13.9 & -6.9342 & 0.0000 \\
Western (Region 4) & 09.5 & 19.9 & 14.1 & -35.2452 & 0.0000 \\
Southern (Region 5) & 42.1 & 20.7 & 32.8 & 32.1642 & 0.0000 \\
\hline Source: Authrs Compution
\end{tabular}

Source: Author's computations based on data from the 2008 ENV survey

The study found that more than $80 \%$ of heads of households in urban and rural areas were male. On average, urban households were smaller than rural ones and were headed by people with a higher level of education. The average age for heads of households was about 40 years.

The 31 administrative regions of Côte d'Ivoire were grouped into 5 major agro-ecological regions that are homogeneous in terms of food production (Yao et al., 2013). The southern region, which includes the district of Abidjan, had the largest proportion of urban households. The respective proportions for the five regions are as follows: $18.7 \%$ for the northern, $17.8 \%$ for the eastern, $11.9 \%$ for the central, $9.5 \%$ for the western, and $42.1 \%$ for the southern region. The northern region had the largest proportion of rural households $(22.7 \%)$. The proportions for the other regions are: $21.7 \%$ for the eastern, $15 \%$ for the central, $19.9 \%$ for the western, and $20.7 \%$ for the southern region.

A better understanding of the differences in the food expenditure structure between high-income households and low-income ones is essential for any price policy concerning foodstuffs. It is for this reason that the present study grouped households into three categories of income, from the lowest to the highest (low, middle, high), according to their average annual nominal prices.

Table 4 shows how expenditure was allocated between food items and non-food products by income group and area of residence (urban and rural).

Table 4: Allocation of expenditures between food and non-food products

\begin{tabular}{l|ccc|cc}
\hline & \multicolumn{3}{|c|}{ Income group } & \multicolumn{2}{c}{ Area of residence } \\
Consumer goods & Low & Middle & High & Urban & Rural \\
\hline Food products (\%) & 46.2 & 42.1 & 36.9 & 45.7 & 37.1 \\
Non-food products (\%) & 53.8 & 57.9 & 63.1 & 54.3 & 62.9 \\
\hline
\end{tabular}

Source: Author's computations based on data from the 2008 ENV survey

Table 4 clearly shows that the structure of household expenditures varied according to income groups. The low-income households allocated a greater amount of their total budget to food items $(46.2 \%)$ than the middle-income households $(42 \%)$ and the high-income ones (36.9\%). This result was expected; it is indeed consistent with Engel's 
law of food expenditures.

Table 4 also presents the average budget shares that were allocated to the different goods by both the rural and urban households. On average, the urban households allocated a higher share of their budget to food expenditures (45.7\%) than the rural ones (37.1\%). This can partly be explained by the higher prices for the main staple foods (tubers, cereals, meat, fish, fruit and vegetables) in the urban than in the rural areas, since the latter ones are those that produce food. Table 5 indicates the allocation of food expenditures per income group and area of residence.

Table 5: Allocation of food expenditures: Differences between income groups and urban and rural areas

\begin{tabular}{l|ccc|cc}
\hline & \multicolumn{3}{|c|}{ Income groups } & \multicolumn{2}{c}{ Area of residence } \\
Foodstuffs & Low & Middle & High & Urban & Rural \\
\hline Cereals &. $\mathbf{3 4 5}$ &. $\mathbf{3 0 4 9}$ & $\mathbf{. 3 0 4 5}$ & $\mathbf{. 3 1 8 2}$ &. $\mathbf{3 1 7 1}$ \\
Rice & .141 & .12 & .127 & .13 & .105 \\
Maize & .126 & .067 & .066 & .048 & .081 \\
Wheat (bread) & .068 & .108 & .104 & .131 & .123 \\
Other cereals & .010 & .0089 & .0075 & .0092 & .0081 \\
Tubers &. $\mathbf{2 6 2 1}$ &. $\mathbf{2 4 5 7}$ &. $\mathbf{1 9 4 7}$ &. $\mathbf{2 3 7 6}$ &. $\mathbf{2 1 2 9}$ \\
Yam & .071 & .085 & .059 & .069 & .066 \\
Cassava & .186 & .155 & .131 & .164 & .142 \\
Other tubers & .0051 & .0047 & .0047 & .0046 & .0049 \\
Fruit and vegetables & .2138 & .2084 & .237 &. $\mathbf{1 9 4 3}$ &. $\mathbf{2 2 9}$ \\
Plantain & .069 & .081 & .097 & .079 & .089 \\
Vegetables & .136 & .117 & .129 & .106 & .129 \\
Other fruit and vegetables & .0088 & .0099 & .011 & .0093 & .011 \\
Meat products &. $\mathbf{1 7 7}$ & .239 & .2616 &. $\mathbf{2 4 8 2}$ & .2399 \\
Meat & .065 & .091 & .118 & .079 & .112 \\
Fish & .106 & .141 & .136 & .162 & .121 \\
Other meat products & .006 & .0069 & .0076 & .0072 & .0069 \\
\hline
\end{tabular}

Source: Author's computations based on data from the $2008 \mathrm{ENV}$ survey

It transpires from Table 5 that rice, meat, fish, cassava, and bread were the staple foods in Côte d'Ivoire. Rice represented the largest share of food expenditure for all income groups. The share of food expenditure allocated to rice by the low-income group was higher than that allocated by the other groups. On the other hand, the share of the expenditure on meat and fish, which are relatively expensive sources of calories, was highest for the households in the high-income group.

\section{Results of Econometric Estimations}

A rejection of the hypothesis of separability of preferences enabled the present study to estimate a food demand model with two levels: a within-group demand system and a demand system for the nine main disaggregated food products.

The systems for the equations for the expenditure shares include household demographic factors as independent variables (see Equations 6 and 7). The properties of symmetry $\left(\gamma_{i j}=\gamma_{j i}\right)$, aggregation $\left(\sum_{i} \alpha_{i}=1\right)$, and homogeneity $\left(\sum_{i} \beta_{i}=0 ; \sum_{i} \gamma_{i j}=0 ; \sum_{i} \lambda_{i}=0 ; i, j=1, \ldots n\right)$ are directly imposed on the system. These different parameters are specified in Equations 6 and 7. The expenditure elasticities and the price elasticities were derived from the following respective formulas: $e_{i}=1+\frac{\mu_{i}}{w_{i}}$ with $\mu_{i}=\frac{\partial w_{i}}{\partial \ln R}$ (expenditure elasticities) and $e_{i j}=\frac{\mu_{i j}}{w_{i}}-\delta_{i j}$ where $\mu_{i j}=\frac{\partial w_{i}}{\partial \ln p_{j}}$ with $\delta_{i j}=1$ if $i=j$ and $\delta_{i j}=0$ if $i \neq j$ (price elasticities). 
8.1 Estimation of the between-group Demand System

The between-group demand was estimated as a system of four equations (cereals, tubers, fruit/vegetables, and animal products) using a Seemingly-Unrelated-Regression (SUR) procedure. One of the equations was excluded in order to ensure the non-singularity of the system. The parameters of the equation in question were, however, recovered by using the restrictions related to symmetry, additivity and homogeneity of the demand function. The estimations of the between-group demand system are presented below for the entire sample and then by income group.

\section{The parameters estimated for the entire sample}

\section{The expenditure elasticities and the effects of demographic variables}

Table 6 presents the expenditure elasticities and the effects of the demographic variables on household food demand. The chi- 2 value of the Breusch-Pagan test enabled the study to reject the null hypothesis of independence of the expenditure share equations, thus justifying the use of the SUR method. The Fisher statistics computed for each equation indicate that they were all overall significant at the $95 \%$ threshold.

Table 6: Expenditure elasticities and effects of demographic variables on the demand for food clusters (between-group estimation)

\begin{tabular}{|c|c|c|c|c|}
\hline \multirow[b]{2}{*}{ Variables } & \multicolumn{4}{|c|}{ Food Clusters $^{1}$} \\
\hline & CEREA & TUBER & FRULEG. & ANIMA. \\
\hline Expenditure & $.9935031^{* * * *}$ & $\begin{array}{c}.2771577 \\
(1862803)\end{array}$ & $\begin{array}{l}.0382268^{* * * *} \\
(0062023)\end{array}$ & $\begin{array}{c}.0117908^{*} \\
(0070858)\end{array}$ \\
\hline Expenditure $^{2}$ & $\begin{array}{c}-.0433882^{* * *} \\
(.011548)\end{array}$ & $\begin{array}{c}.0072226 \\
(.0067658)\end{array}$ & $\begin{array}{c}-.0032731^{* * * *} \\
(.0011534)\end{array}$ & $\begin{array}{l}-.030233^{* *} \\
(.0133082)\end{array}$ \\
\hline Household size & $\begin{array}{l}.0377038^{* * *} \\
(.0040334)\end{array}$ & $\begin{array}{c}.0009814 \\
(.0023631)\end{array}$ & $\begin{array}{c}.0161387 \\
(.0909218)\end{array}$ & $\begin{array}{c}.0037519 \\
(.0024749)\end{array}$ \\
\hline Rural & $\begin{array}{c}-.2049642^{* * *} \\
(.0234925)\end{array}$ & $\begin{array}{l}-.184015^{* * *} \\
(.0137641)\end{array}$ & $\begin{array}{c}-.0001855 \\
(.0033023)\end{array}$ & $\begin{array}{c}-.1637143^{\text {**** }} \\
(.0144149)\end{array}$ \\
\hline Female & $\begin{array}{c}.0172431 \\
(.0216888)\end{array}$ & $\begin{array}{l}-.0058598 \\
(.0127073)\end{array}$ & $\begin{array}{l}-.0005814 \\
(.0162238)\end{array}$ & $\begin{array}{l}-.2982167 \\
(.1950888)\end{array}$ \\
\hline \multicolumn{5}{|c|}{ Level of formal education } \\
\hline Without formal educ. & -- & -- & -- & -- \\
\hline Primary school & $\begin{array}{l}-.0505511 \\
(.0373307)\end{array}$ & $\begin{array}{l}.0406144^{*} \\
(.0218717)\end{array}$ & $\begin{array}{c}.0255371 \\
(.0240626)\end{array}$ & $\begin{array}{l}-.0051405 \\
(.0229059)\end{array}$ \\
\hline Secondary school & $\begin{array}{l}-.0510396 \\
(.056733)\end{array}$ & $\begin{array}{c}.0082048 \\
(.0332393)\end{array}$ & $\begin{array}{l}.0632486^{* * * *} \\
(.0067181)\end{array}$ & $\begin{array}{l}-.0450009 \\
(.0348111)\end{array}$ \\
\hline Higher & $\begin{array}{l}-.0654772 \\
(.0841443)\end{array}$ & $\begin{array}{c}.05948 \\
(.0492994)\end{array}$ & $\begin{array}{l}.0247014^{* *} \\
(.0106754)\end{array}$ & $\begin{array}{c}-.054762 \\
(.0516305)\end{array}$ \\
\hline Age & $\begin{array}{c}-.0021623^{* * *} \\
(.0006173)\end{array}$ & $\begin{array}{l}-.0001003 \\
(.0003616)\end{array}$ & $\begin{array}{l}-.0003423^{*} \\
(.0001765)\end{array}$ & $\begin{array}{l}-.0008686^{* *} \\
(.0003788)\end{array}$ \\
\hline Constant & $\begin{array}{l}4.867903^{* *} \\
(2.189675)\end{array}$ & $\begin{array}{c}2.820369^{* * *} \\
(1.28291)\end{array}$ & $\begin{array}{c}.006686 \\
(.6261773) \\
\end{array}$ & $\begin{array}{c}2.152845 \\
(1.343574)\end{array}$ \\
\hline No. of observations & 9817 & 9817 & 9817 & 9817 \\
\hline$F$-stat & 26.57 & 25.49 & 22.05 & 23.34 \\
\hline$P$-value & 0.0000 & 0.0000 & 0.0000 & 0.0000 \\
\hline \multicolumn{3}{|c|}{ Breusch-Pagan test of independence: Chi 2(6): 221.874} & \multicolumn{2}{|c|}{ P-value: 0.0000} \\
\hline
\end{tabular}

'. CEREA=Cereals; TUBER=Tubers; FRULEG=Fruit and vegetables; ANIMA=Animal Products Source: Author's computations based on data from the 2008 ENV survey

The standard deviations are given in parentheses; *** means significant at $1 \%$, ** at $5 \%$, and * at $10 \%$ 
With the exception of the equation for tubers, the quadratic expenditure terms were found to be statistically significant, thus justifying the QUAIDS specification.

The expenditure coefficients indicate positive and significant effects of income on the budget allocated to food clusters, with the exception of tubers. This result means that as expenditures rise, the shares of cereals, fruit and vegetables, and animal products in the food budget increase as well. So, with their expenditure elasticities being positive and lower than 1, the food clusters studied can all be considered to be staple foods.

This result is similar to that reported in previous research (Camara \& Dramane, 1992). However, animal products seem to be food items that are out of reach for low-income families. More detailed estimations would enable a verification of the status of animal products by income group.

The sociodemographic variables included in the present study are: household size, area of residence (urban or rural), gender, and educational level of the head of household. The parameters related to these variables in the expenditure share equations were found to be significant. This means that food spending habits varied according to household sociodemographic characteristics.

In relation to household structure, being a large household significantly increased the share of cereals in the food budget. This means that cereals constituted the most accessible sources of calories for big households. With regard to area of residence, the study found that rural households allocated a lower share of their budget to cereals, tubers and animal products than their urban counterparts. Eating habits were also found to vary among households according to the educational level of the head of the household: households headed by someone with a secondary or higher level of education allocated a higher share of their food budget to fruit and vegetables. Finally, food expenditures varied according to the age of the head of the household. For instance, the share of the food budget allocated to cereals and animal products was found to reduce significantly as the head of the household got older.

\section{Direct and cross price elasticities}

The direct and cross price elasticities ${ }^{2}$ of demand for foodstuffs are presented in Table 7. The direct price elasticities appear on the diagonal of the matrix.

Table 7: Direct and cross elasticities of demand for food clusters

\begin{tabular}{|l|c|c|c|c|}
\hline \multirow{2}{*}{ Food clusters } & \multicolumn{3}{|c|}{ PRICE } \\
\cline { 2 - 5 } & CEREA & TUBER & FRULEG & ANIMA \\
\hline CEREA & $-.037756^{* * *}$ & $.012511^{* * *}$ & $-.012829^{* * *}$ & $-.005219^{*}$ \\
\hline TUBER & $.026301^{* * * *}$ & $-.027488^{* * *}$ & $-.017660^{* * *}$ & -.010972 \\
\hline FRU-LEG & $-.051391^{* *}$ & $-.033651^{* * *}$ & $-.119381^{* * *}$ & -.033651 \\
\hline ANIMA & $-.014564^{* *}$ & $-.014564^{* * * *}$ & $-.023441^{* *}$ & $-.029121^{* * *}$ \\
\hline
\end{tabular}

${ }^{\mathrm{a}}$ CEREA=Cereals, TUBER=Tubers, FRU-LEG=Fruit and vegetables, ANIMA=Animal products

Source: Author's computations based on data from the 2008 ENV survey

The standard deviations are given in parentheses; *** means significant at $1 \%, * *$ at $5 \%$, and $*$ at $10 \%$

\footnotetext{
${ }^{2}$ Their values were obtained from the parameters of the equation of budget shares (Table A4, Annex 3).
} 
Table 7 indicates that all direct price elasticities were negative and statistically significant. With elasticities lower than 1 (in absolute values), all the food clusters were found to be inelastic to variations in their price index. This result is consistent with the literature that established that the demand for food goods was inelastic (Allen, 2010). For the entire sample, tubers were found to be the least sensitive to price variations.

For their part, the cross price elasticities were all found to be statistically different from zero. This means that price changes in one of the food clusters affected the expenditure shares allocated to the other clusters. The same result highlights a single substitutability relationship between tubers and cereals: an increase in the price of cereals had a positive impact on the demand for tubers, and the other way around. On the other hand, complementarity effects were observed between all other pairs of food clusters. Indeed, animal products and fruit and vegetables constituted a complementary intake for the other food clusters and were complementary to each other.

\section{The QUAIDS model's parameters estimated according to income group}

The expenditure elasticities and the price elasticities by income group are presented in Table 8.

\section{The expenditure elasticities}

The expenditure elasticities were not found to be statistically different from zero for tubers in all income groups. Similarly, the expenditure elasticity of demand for fruit and vegetables was not significant for high-income households. All other expenditure elasticities were found to be positive and significant, in line with the literature (Bopape, 2006). The related quadratic terms were also found to be statistically significant.

With expenditure elasticities higher than 1, only animal products were found to be luxury goods for low-income and middle-income households; however, they were found to be staple foods for high-income households.

The elasticity for cereals was found to be significant and lower than 1, which means that cereals were a staple food for all income groups. Moreover, the significant and lower-than-1 expenditure elasticity obtained for the low-income and middle-income households means that fruit and vegetables were staple foods for these two income groups.

\section{The price elasticities}

Table 8 shows that the direct price elasticities by income group were all significant and negative. This means that all the food clusters, with the exception of animal products, had an inelastic demand.

With a price elasticity of higher than 1 (in absolute value), the demand for animal products was found to be elastic for the low-income and middle-income households. This observation is consistent with the expenditure elasticity (significantly higher than 1) obtained for the two income groups (low income and middle income) and is also consistent with the idea that animal products are luxury goods for less wealthy households. All other food clusters (cereals, tubers, fruit and vegetables) showed direct price elasticities that were, in absolute value, lower than 1 , meaning a weak sensitivity of the demand for these foodstuffs to price variations for all the income groups. 
Table 8: Expenditure elasticities and price elasticities of the between-group food demand by income group

\begin{tabular}{|c|c|c|c|c|c|c|c|c|c|c|c|c|}
\hline & \multicolumn{12}{|c|}{ Income group } \\
\hline & \multicolumn{4}{|c|}{ Low income } & \multicolumn{4}{|c|}{ Middle income } & \multicolumn{4}{|c|}{ High income } \\
\hline & CER & TUB & FRU & ANI & CER & TUB & FRU & ANI & CER & TUB & FRU & ANI \\
\hline Expenditure & $\begin{array}{l}.1761126^{*} \\
(.0941469)\end{array}$ & $\begin{array}{l}-.0917383 \\
(.1085778)\end{array}$ & $\begin{array}{l}.2636373^{\text {**** }} \\
(.1011558)\end{array}$ & $\begin{array}{l}1.348011^{* * *} \\
(.0444209)\end{array}$ & $\begin{array}{l}.095956^{* *} \\
(.0489198)\end{array}$ & $\begin{array}{c}.024247 \\
(.0749336)\end{array}$ & $\begin{array}{l}.155376^{* * *} \\
(.0701228)\end{array}$ & $\begin{array}{c}1.275580^{* * * *} \\
(.0303826)\end{array}$ & $\begin{array}{l}.319883^{* *} \\
(.1409138)\end{array}$ & $\begin{array}{c}.0367463 \\
(.1617866)\end{array}$ & $\begin{array}{c}.1534782 \\
(.1352793)\end{array}$ & $\begin{array}{l}.510108^{\text {**** }} \\
(.0720651)\end{array}$ \\
\hline Expenditure $^{2}$ & $\begin{array}{l}-.0076936^{*} \\
(.0045235)\end{array}$ & $\begin{array}{c}.0070848 \\
(.0052169)\end{array}$ & $\begin{array}{l}-.011974^{* * *} \\
(.0048602)\end{array}$ & $\begin{array}{l}-.01258^{* * *} \\
(.0021343)\end{array}$ & $\begin{array}{l}-.0041991^{*} \\
(.0022162)\end{array}$ & $\begin{array}{c}.00105 \\
(.0033947)\end{array}$ & $\begin{array}{l}-.006307^{* *} \\
(.0031768)\end{array}$ & $\begin{array}{c}-.00945^{* * * *} \\
(.0013764)\end{array}$ & $\begin{array}{l}-.013467^{* *} \\
(.0059527)\end{array}$ & $\begin{array}{c}.000847 \\
(.0068344)\end{array}$ & $\begin{array}{l}-.0059795 \\
(.0057147)\end{array}$ & $\begin{array}{c}-.01860^{* * * *} \\
(.0030443)\end{array}$ \\
\hline CER price & $\begin{array}{c}-.055^{* * *} \\
(.000617)\end{array}$ & $\begin{array}{c}.027^{* * *} \\
(.0007116)\end{array}$ & $\begin{array}{c}-.00895^{* *} \\
(.0006629)\end{array}$ & $\begin{array}{c}-.0003675 \\
(.0002674)\end{array}$ & $\begin{array}{l}-.023376^{* * * *} \\
(.0004113)\end{array}$ & $\begin{array}{c}-.00377^{* * * *} \\
(.00063)\end{array}$ & $\begin{array}{l}-.045534^{* * * *} \\
(.0005895)\end{array}$ & $\begin{array}{c}-.0002585 \\
(.0002554)\end{array}$ & $\begin{array}{c}-.0958^{* * *} \\
(.0003945)\end{array}$ & $\begin{array}{c}-.0002398 \\
(.0001393)\end{array}$ & $\begin{array}{c}-.04628338^{*} \\
(.0002662)\end{array}$ & $\begin{array}{l}-.155033^{* * *} \\
(.0002017)\end{array}$ \\
\hline TUB price & $\begin{array}{c}.0501^{* * * *} \\
(.0001542)\end{array}$ & $\begin{array}{l}-.03065^{* * *} \\
(.0001778)\end{array}$ & $\begin{array}{l}-.06819^{* * * *} \\
(.0001657)\end{array}$ & $\begin{array}{c}-.352353^{* * *} \\
(.0003084)\end{array}$ & $\begin{array}{l}-.01980^{* * * *} \\
(.00009)\end{array}$ & $\begin{array}{l}-.00635^{* * * *} \\
(.0001378)\end{array}$ & $\begin{array}{c}-.036405^{* * *} \\
(.0003286)\end{array}$ & $\begin{array}{c}-.3121^{* * * *} \\
(.0004126)\end{array}$ & $\begin{array}{l}-.001038 \\
(.0004529)\end{array}$ & $\begin{array}{c}-.0054^{* * *} \\
(.0001599)\end{array}$ & $\begin{array}{c}-.028952^{* * *} \\
(.0003056)\end{array}$ & $\begin{array}{c}-.098768^{* * * *} \\
(.000191)\end{array}$ \\
\hline FRU price & $\begin{array}{l}-.03621^{* * * *} \\
(.0003034)\end{array}$ & $\begin{array}{l}-.02051^{* * * *} \\
(.0003499)\end{array}$ & $\begin{array}{l}-.05489^{* * * *} \\
(.000326)\end{array}$ & $\begin{array}{c}-.0004425 \\
(.0002873)\end{array}$ & $\begin{array}{c}-.01815^{* * * *} \\
(.0002145)\end{array}$ & $\begin{array}{l}-.00328^{* * *} \\
(.000129)\end{array}$ & $\begin{array}{c}-.0233^{* * * *} \\
(.0003075)\end{array}$ & $\begin{array}{l}-.26517^{* * * *} \\
(.0003861)\end{array}$ & $\begin{array}{l}-.07531^{* * * *} \\
(.0003787)\end{array}$ & $\begin{array}{l}-.0077^{* * * *} \\
(.0001337)\end{array}$ & $\begin{array}{l}-.034874^{* * *} \\
(.0002556)\end{array}$ & $\begin{array}{c}-.0001638 \\
(.0001603)\end{array}$ \\
\hline ANI price & $\begin{array}{c}-.0003158 \\
(.0002911)\end{array}$ & $\begin{array}{l}-.01719^{* * *} \\
(.0003084)\end{array}$ & $\begin{array}{c}-.0000673 \\
(.0001432)\end{array}$ & $\begin{array}{l}-1.0017^{* * * *} \\
(.0001262)\end{array}$ & $\begin{array}{c}-.0002226 \\
(.0002694)\end{array}$ & $\begin{array}{l}-.004575^{* * *} \\
(.0000559)\end{array}$ & $\begin{array}{l}-.03647^{* * *} \\
(.0001332)\end{array}$ & $\begin{array}{c}-1.00210^{* * * *} \\
(.0001673)\end{array}$ & $\begin{array}{l}-.08323^{* * * *} \\
(.000167)\end{array}$ & $\begin{array}{l}-.00906^{* * * *} \\
(.0000712)\end{array}$ & $\begin{array}{l}-.03998^{* * * *} \\
(.0001361)\end{array}$ & $\begin{array}{l}-.125234^{* * * *} \\
(.0000854)\end{array}$ \\
\hline Constant & $\begin{array}{c}-.7387439 \\
(.4576333)\end{array}$ & $\begin{array}{c}.3847586 \\
(.5277795)\end{array}$ & $\begin{array}{l}1.078222^{* *} \\
(.4917026)\end{array}$ & $\begin{array}{c}2.43220^{* * * *} \\
(.215923)\end{array}$ & $\begin{array}{c}-.3974624 \\
(.2627145)\end{array}$ & $\begin{array}{l}-.0152205 \\
(.4024165)\end{array}$ & $\begin{array}{r}-.6150249 \\
(.376581)\end{array}$ & $\begin{array}{l}2.0277^{* * *} \\
(.163164)\end{array}$ & $\begin{array}{l}1.544126^{*} \\
(.8209725)\end{array}$ & $\begin{array}{l}-.2343696 \\
(.9425789)\end{array}$ & $\begin{array}{c}-.7477593 \\
(.7881456)\end{array}$ & $\begin{array}{l}3.52625^{* * *} \\
(.4198559)\end{array}$ \\
\hline $\begin{array}{l}\text { No. of obs. } \\
R \text { squared } \\
\text { Chi } 2\end{array}$ & $\begin{array}{c}2454 \\
0.52 \\
138.95^{* * * *}\end{array}$ & $\begin{array}{c}2454 \\
0.37 \\
83.35^{\text {*** }}\end{array}$ & $\begin{array}{c}2454 \\
0.34 \\
53.67^{* * * *}\end{array}$ & $\begin{array}{c}2454 \\
0.82 \\
587.47^{* * *}\end{array}$ & $\begin{array}{c}4909 \\
0.6038 \\
263.60^{* * * *}\end{array}$ & $\begin{array}{c}4909 \\
0.4043 \\
117.40^{* * * *}\end{array}$ & $\begin{array}{c}4909 \\
0.3955 \\
113.17^{* * * *}\end{array}$ & $\begin{array}{l}4909 \\
0.7587 \\
543.86^{* * *}\end{array}$ & $\begin{array}{c}2454 \\
0.3404 \\
32.03^{* * *}\end{array}$ & $\begin{array}{c}2454 \\
0.4165 \\
45.69^{* * *}\end{array}$ & $\begin{array}{c}2454 \\
0.4516 \\
52.71^{* * * *}\end{array}$ & $\begin{array}{c}2454 \\
0.7882 \\
238.16^{* * *}\end{array}$ \\
\hline
\end{tabular}

Note: $\mathrm{CER}=$ Cereals, TUB=Tubers, FRU=Fruit and vegetables, ANI=Animal products

Source: Author's computations based on the 2008 ENV survey; SDs are in parentheses; ***, **, *: significant at $1 \%, 5 \%$ and $10 \%$. 
Overall, the cross price elasticities were found to be significantly different from zero. The elasticities for low income households were positive for cereals and tubers, which means that these clusters of foods were substitutes. However, they were negative for cereals, fruit and vegetables, as well as for animal products and tubers, meaning that there was complementarity between those food clusters.

The results did not show any substitution effect between the food clusters for the middle-income and high-income groups. All the cross price elasticities for cereals, tubers, animal products, and fruit and vegetables were negative, which means that the four main food clusters were complements for the middle- and high-income households.

This result can be explained by the existence of a correlation between nutritional balance and the household's level of income (Maillot et al., 2007). The well-to-do families (those with middle and high incomes) tend to observe the dietary recommendations ${ }^{3}$ related to a varied diet between food clusters. That is, the desire to observe these recommendations causes the households without many budget constraints to consume the products constituting the four major food clusters in a complementary way. Cereals, tubers, fruit and vegetables, and animal products were thus identified as complementary goods for the middle- and high-income households.

An analysis of aggregate demand for the major food clusters does not enable one to observe the substitute or complementary relationship between food clusters. That is why it becomes necessary to estimate a disaggregated demand system for the main food clusters.

\subsection{The Disaggregated Food Demand System}

The estimations of the demand system for the nine main food clusters are presented for the entire sample. A last equation related to foodstuffs was excluded in order to ensure the non-singularity of the system.

\section{Expenditure elasticities and effects of sociodemographic variables}

The expenditure elasticities and the effects of the socioeconomic and sociodemographic variables on the demand for the main foods are presented in Table 9. The agroecological differences between the main geographical regions have an incidence on household eating habits (Pomboza \& Mbaga, 2007), meaning that eating habits vary from one region to the other. That is why it is important to control for these regional differences while estimating an overall system of food demand.

The Wald Chi-square statistics show that each one of the estimated equations was significant. With the exception of yam, the food products that were analyzed in a disaggregated form presented positive expenditure elasticities. These elasticities were significant for rice, cassava fruit and vegetables, fish, and meat. The significance of the related quadratic terms justifies the choice of a quadratic form. This result means that as food expenditures increase, the share of rice, cassava, fruit and vegetables, fish, and meat in the food budget increases as well. With expenditure elasticities being lower than 1 , all these food commodities can be considered as staple foods.

The estimations of the parameters related to sociodemographic variables were on the whole significant for the regional variables. This means that the food expenditure structure varied from one region to another. However, before any interpretation of such a result, it should be remembered that the region of Abidjan (the country's economic

${ }^{3}$ The dietary recommendations made by public health bodies cover three essential dimensions: variety, moderation, and overall nutritional balance of the shopping basket. 
capital) was used in the present study as the reference variable.

For instance, the study found that households in the Northern region of the country tended to allocate a larger share of their food budget to maize and a smaller share to plantain and meat than households in Abidjan. Households in the Eastern region allocated a larger share of their food budget to plantain and meat, and a smaller share to rice and cassava than the households in Abidjan. The households in the Central region tended to spend less on yam and vegetables and fruit than those in Abidjan. The households in the Western region tended to allocate a smaller share of their food budget to rice, fruit and vegetables than those in Abidjan, while the households in the Southern region allocated a greater share of their food budget to fish than those in Abidjan. 
Table 9: Disaggregated food demand system: expenditure elasticities and effects of demographic variables

\begin{tabular}{|c|c|c|c|c|c|c|c|c|c|}
\hline & Rice & Maize & Wheat & Yam & Cassava & Plantain & Fruit/vegetables & Fish & Meat \\
\hline Expenditure & $\begin{array}{c}.073352^{*} \\
(.0383752)\end{array}$ & $\begin{array}{c}.0022319 \\
(.0308458)\end{array}$ & $\begin{array}{c}.0209059 \\
(.0178173)\end{array}$ & $\begin{array}{c}-.0655169 \\
(.05881)\end{array}$ & $\begin{array}{l}.0816967^{*} \\
(.0486047)\end{array}$ & $\begin{array}{c}.0291937 \\
(.0492227)\end{array}$ & $\begin{array}{l}.139982^{* * \%} \\
(.0330362)\end{array}$ & $\begin{array}{l}.3406797^{* * * *} \\
(.0120257)\end{array}$ & $\begin{array}{l}.0557065^{3 *} \\
(.0257459)\end{array}$ \\
\hline Expenditure $^{2}$ & $\begin{array}{l}-.0033095^{* *} \\
(.0016469)\end{array}$ & $\begin{array}{c}.0008308 \\
(.0013238)\end{array}$ & $\begin{array}{l}-.0009451 \\
(.0007646)\end{array}$ & $\begin{array}{c}.004565^{*} \\
(.0025239)\end{array}$ & $\begin{array}{l}-.0034336^{*} \\
(.0020859)\end{array}$ & $\begin{array}{l}-.0006324 \\
(.0021124)\end{array}$ & $\begin{array}{c}-.0066767^{* * *} \\
(.0014178)\end{array}$ & $\begin{array}{c}-.0117206^{* * *} \\
(.0005161)\end{array}$ & $\begin{array}{l}-.0019661^{*} \\
(.0011049)\end{array}$ \\
\hline Household size & $\begin{array}{l}-.0058156 \\
(.0041567)\end{array}$ & $\begin{array}{l}-.0059095 \\
(.0051713)\end{array}$ & $\begin{array}{l}-.0004052 \\
(.002401)\end{array}$ & $\begin{array}{c}.0057897 \\
(.0079251)\end{array}$ & $\begin{array}{l}-.0085314 \\
(.0065498)\end{array}$ & $\begin{array}{c}.0033863 \\
(.0066331)\end{array}$ & $\begin{array}{c}.004624 \\
(.0044519)\end{array}$ & $\begin{array}{c}.0002176 \\
(.0016206)\end{array}$ & $\begin{array}{c}.006462^{*} \\
(.0034695)\end{array}$ \\
\hline Residence area & $\begin{array}{l}-.0222262 \\
(.0205114)\end{array}$ & $\begin{array}{c}.0002443 \\
(.0255182)\end{array}$ & $\begin{array}{l}-.0043241 \\
(.0118479)\end{array}$ & $\begin{array}{l}-.0021962 \\
(.0391067)\end{array}$ & $\begin{array}{l}-.0127525 \\
(.0323205)\end{array}$ & $\begin{array}{l}-.0172633 \\
(.0327314)\end{array}$ & $\begin{array}{c}.0295436 \\
(.0219679)\end{array}$ & $\begin{array}{c}.0101535 \\
(.0079967)\end{array}$ & $\begin{array}{c}.0184373 \\
(.0171202)\end{array}$ \\
\hline Sex & $\begin{array}{l}-.0046657 \\
(.018596)\end{array}$ & $\begin{array}{l}-.0263712 \\
(.0231353)\end{array}$ & $\begin{array}{l}-.0000806 \\
(.0107416)\end{array}$ & $\begin{array}{c}.0382738 \\
(.0354549)\end{array}$ & $\begin{array}{c}.0032513 \\
(.0293024)\end{array}$ & $\begin{array}{c}.016705 \\
(.029675)\end{array}$ & $\begin{array}{l}-.0239867 \\
(.0199166)\end{array}$ & $\begin{array}{l}-.0071442 \\
(.0089205)\end{array}$ & $\begin{array}{l}-.0159318 \\
(.0155215)\end{array}$ \\
\hline Education & $\begin{array}{c}.0344881 \\
(.0228809)\end{array}$ & $\begin{array}{l}-.0160894 \\
(.0284661)\end{array}$ & $\begin{array}{c}.0060786 \\
(.0132166)\end{array}$ & $\begin{array}{c}.0196997 \\
(.0245057)\end{array}$ & $\begin{array}{c}.0053147 \\
(.0190979)\end{array}$ & $\begin{array}{l}-.0187458 \\
(.0365126)\end{array}$ & $\begin{array}{l}.0848202^{*} \\
(.0436242)\end{array}$ & $\begin{array}{c}.0133505^{*} \\
(.00725)\end{array}$ & $\begin{array}{l}.0609682^{*} \\
(.0360541)\end{array}$ \\
\hline $\begin{array}{l}\text { Northern } \\
\text { region }\end{array}$ & $\begin{array}{c}.0440504 \\
(.0361783)\end{array}$ & $\begin{array}{l}.1131532^{* *} \\
(.0450094)\end{array}$ & $\begin{array}{c}.0043074 \\
(.0208975)\end{array}$ & $\begin{array}{l}-.0184375 \\
(.0689768)\end{array}$ & $\begin{array}{l}-.0817221 \\
(.0570073)\end{array}$ & $\begin{array}{l}-.1236348^{* *} \\
(.0577321)\end{array}$ & $\begin{array}{c}-.059729 \\
(.0387473)\end{array}$ & $\begin{array}{c}.0121786 \\
(.0141047)\end{array}$ & $\begin{array}{c}-.1124219^{* * * *} \\
(.0301968)\end{array}$ \\
\hline Eastern region & $\begin{array}{c}-.1387035^{\text {**** }} \\
(.0330426)\end{array}$ & $\begin{array}{l}-.0472319 \\
(.0411083)\end{array}$ & $\begin{array}{c}.0006967 \\
(.0190863)\end{array}$ & $\begin{array}{l}-.0780991 \\
(.0629984)\end{array}$ & $\begin{array}{l}-.0871658^{*} \\
(.0520663)\end{array}$ & $\begin{array}{l}.1397026^{* * *} \\
(.0527283)\end{array}$ & $\begin{array}{l}.0335901 \\
(.035389)\end{array}$ & $\begin{array}{c}.0010414 \\
(.0709776)\end{array}$ & $\begin{array}{l}.1417217^{* * *} \\
(.0275795)\end{array}$ \\
\hline Central region & $\begin{array}{c}.0185776 \\
(.0680432)\end{array}$ & $\begin{array}{l}-.0637557 \\
(.1297298)\end{array}$ & $\begin{array}{c}-.002689 \\
(.0393036)\end{array}$ & $\begin{array}{c}-.3373802^{* * *} \\
(.0846525)\end{array}$ & $\begin{array}{l}-.0638112 \\
(.1072178)\end{array}$ & $\begin{array}{l}-.0997313 \\
(.1085811)\end{array}$ & $\begin{array}{c}-.1354589^{*} \\
(.072875)\end{array}$ & $\begin{array}{c}.0159237 \\
(.0265277)\end{array}$ & $\begin{array}{l}-.0031072 \\
(.0567933)\end{array}$ \\
\hline Western region & $\begin{array}{c}-.3006587^{* * *} \\
(.0739543)\end{array}$ & $\begin{array}{c}-.0225942 \\
(.059444)\end{array}$ & $\begin{array}{l}-.0177704 \\
(.0343365)\end{array}$ & $\begin{array}{c}.0808287 \\
(.1133348)\end{array}$ & $\begin{array}{c}-.062568 \\
(.0936678)\end{array}$ & $\begin{array}{l}-.1331738 \\
(.0948588)\end{array}$ & $\begin{array}{l}-.1081124^{*} \\
(.0636652)\end{array}$ & $\begin{array}{l}-.0261293 \\
(.0231752)\end{array}$ & $\begin{array}{l}-.0062768 \\
(.0496159)\end{array}$ \\
\hline $\begin{array}{l}\text { Southern } \\
\text { region }\end{array}$ & $\begin{array}{c}.0027445 \\
(.1820566)\end{array}$ & $\begin{array}{c}.076569 \\
(.2264966)\end{array}$ & $\begin{array}{c}.022738 \\
(.1051608)\end{array}$ & $\begin{array}{l}-.1950806 \\
(.3471057)\end{array}$ & $\begin{array}{c}.0776701 \\
(.2868725)\end{array}$ & $\begin{array}{l}-.0605524 \\
(.2905201)\end{array}$ & $\begin{array}{c}.0829509 \\
(.1949846)\end{array}$ & $\begin{array}{c}-.0379435^{* * *} \\
(.0128822)\end{array}$ & $\begin{array}{l}-.0096558 \\
(.1519565)\end{array}$ \\
\hline Constant & $\begin{array}{l}-.1180491 \\
(.184069)\end{array}$ & $\begin{array}{l}-.2493805 \\
(.2290002)\end{array}$ & $\begin{array}{l}-.0870547 \\
(.1063232)\end{array}$ & $\begin{array}{c}.3374215 \\
(.3509424)\end{array}$ & $\begin{array}{l}-.2758833 \\
(.2900434)\end{array}$ & $\begin{array}{l}-.0692344 \\
(.2937314)\end{array}$ & $\begin{array}{c}-.6040492^{* * *} \\
(.1971399)\end{array}$ & $\begin{array}{l}2.447937^{* * *} \\
(.0717622)\end{array}$ & $\begin{array}{c}-.3971625^{* * * *} \\
(.1536362)\end{array}$ \\
\hline No. of Obs. & 9817 & 9817 & 9817 & 9817 & 9817 & 9817 & 9817 & 9817 & 9817 \\
\hline $\begin{array}{l}\text { R Squared } \\
\text { Chi } 2\end{array}$ & $\begin{array}{c}0.5199 \\
395.23^{* * *}\end{array}$ & $\begin{array}{c}0.5774 \\
498.66^{* * *}\end{array}$ & $\begin{array}{c}0.3895 \\
232.84^{* * *}\end{array}$ & $\begin{array}{c}0.3985 \\
241.81^{* * * *}\end{array}$ & $\begin{array}{c}0.7024 \\
861.64^{* * *}\end{array}$ & $\begin{array}{c}0.4099 \\
253.49^{* * *}\end{array}$ & $\begin{array}{c}0.5560 \\
457.03^{* * *}\end{array}$ & $\begin{array}{c}0.9296 \\
4821.44^{* * *}\end{array}$ & $\begin{array}{c}0.6232 \\
603.76^{* * *}\end{array}$ \\
\hline
\end{tabular}

Source: Author's computations based on the 2008 ENV survey; SDs are in parentheses; ***,**, *: significant at $1 \%, 5 \%$ and $10 \%$. 
The results show that the educational level of the head of household was a relevant variable in accounting for the food expenditure structure: the households whose head had at least a primary school education allocated a larger share of their food budget to fruit and vegetables and animal proteins (fish and meat). This result can be explained by the fact that the heads of household in this category have preferences for rich foods (fruit and vegetables, fish, etc.), in terms of nutritional intake, and are relatively well-to-do.

\section{Direct and cross price elasticities of the disaggregated food demand system}

Table 10 presents both the direct and the cross price elasticities ${ }^{4}$ of the disaggregated food demand system. The estimations of the direct price elasticities (on the diagonal of the matrix) are consistent with economic theory and empirical literature (Allen, 2010). They were all found to be negative and significant at the $1 \%$ significance level. The fact that these elasticities were lower than 1 means that the demand was inelastic for all the main food products studied.

The cross price elasticities of the demand system for the nine main products are also presented in Table 10. Rice, yam and cassava showed positive cross price elasticities, meaning that these foods were net substitutes. Maize, yam and plantain were also considered by households as substitutes. However, no substitution was established among the cereals themselves, but it was between cereals and starchy foods, a result which is different from those obtained in the other studies conducted in Africa and which highlighted substitution between rice and the other cereals (Erhabor \& Ojogho, 2011; Weliwita et al., 2003).

Negative cross price elasticities were observed for animal products (meat and fish) and for each of the following foods: maize, yam, cassava and plantain. This observation means that meat and fish were considered by households as complements to maize and the main starchy foods (yam, cassava, and plantain). Similarly, the negative and significant sign of the cross elasticities between fruit and vegetables and the main starchy foods means that each of the latter was a net complement to fruit and vegetables. This observation is similar to that made by Ulimwengu et al. (2012), which established significant effects of complementarity between vegetables, starchy foods and animal products in the diet of households in the Democratic Republic of Congo.

\footnotetext{
${ }^{4}$ Values of price elasticities were obtained from price parameters of the equations of budget shares for disaggregated food demand system.
} 
Table 10: Disaggregated food demand system: direct and cross price elasticities

\begin{tabular}{|c|c|c|c|c|c|c|c|c|c|}
\hline & Rice & Maize & Wheat & Yam & Cassava & Plantain & Fruit/vegetables & Fish & Meat \\
\hline Rice & $-0.0080159^{* * * *}$ & -.0002082 & -0.0080221 & $0.0102068^{* * * *}$ & $0.0101999^{\text {*** }}$ & -0.0033538 & -0.0164731 & $-0.0408282^{* * *}$ & $-0.000613^{*}$ \\
\hline Maize & -0.0041718 & $-.0022317^{* * *}$ & -0.0042852 & $0.0057525^{* * *}$ & 0.004794 & $0.0021962^{* * *}$ & $-0.0076686^{* *}$ & -0.0203113 & $-.0001966^{* *}$ \\
\hline Wheat & 0.0093279 & -.0003552 & $-0.0123011^{* * *}$ & -0.0106281 & -0.0099953 & $0.0046221^{* *}$ & -0.0178286 & -0.044236 & -0.000545 \\
\hline Yam & $0.005368^{* * *}$ & $0.00100274^{* * *}$ & -0.0044456 & $-0.00520692^{* * *}$ & $0.00615752^{* * *}$ & $0.00212586^{* * *}$ & $-0.0082231^{* * *}$ & -0.0228235 & $-.0002701^{* * *}$ \\
\hline Cassava & $0.0113471^{* *}$ & -0.0002271 & -0.0104494 & $0.0128561^{* * *}$ & $-0.0108348^{* * *}$ & $0.0047891^{* * *}$ & $-0.0201949^{* *}$ & -0.0508424 & -0.0007616 \\
\hline Plantain & -0.0056694 & $0.0006124^{* * *}$ & $0.004436^{* *}$ & $0.0066639^{* * *}$ & $0.0069188^{* * *}$ & $-0.001535^{* * *}$ & $-0.0103398^{* *}$ & -0.0270378 & $-0.0003075^{* * *}$ \\
\hline Fruit/vegetables & -0.0077151 & $-.0007254^{* * *}$ & -0.0075634 & $-0.0076958^{* * *}$ & $-0.0081958^{* *}$ & $-0.0023785^{* *}$ & $-0.0111494^{* * *}$ & 0.0373877 & -0.0004252 \\
\hline Fish & $-0.0101762^{* *}$ & -0.0001875 & -0.009212 & -0.0110993 & -0.011189 & -0.0039016 & -0.0195077 & $-0.0473233^{* * *}$ & 0.001115 \\
\hline Meat & $-0.0072446^{*}$ & $-0.000264^{* *}$ & -0.0067291 & $-0.0078989^{* * *}$ & -0.0080951 & $-0.0027989^{* * * *}$ & -0.0138025 & 0.0343952 & $-0.00213^{* * *}$ \\
\hline
\end{tabular}

Note: These elasticities were calculated on the basis of the price parameters.

Source: Author's computations based on the 2008 ENV survey; SDs are in parentheses; ***, **, *: significant at $1 \%, 5 \%$ and 10 


\subsection{Price Variation and Well-being Measurement}

The 2007-2008 global food price crisis had a sudden impact on the food market in Côte d'Ivoire, causing a rise in the prices of imported staple foods, particularly rice and meat (according to the Ministry of Agriculture [MINAGRI] and the INS, 2011). That is why the present study sought to assess the monetary impact of the prices of rice and meat in the country. The reference year is 2008, which is that of the last survey of household living standards in Côte d'Ivoire.

The choice of rice and meat for the analysis of well-being was motivated by the strong dependency on the fluctuations in the global prices of these imported foodstuffs, prices which saw big increases between 2008 and 2012: the average prices of imported staple rice and meat that were CFAF 315 and CFAF 1,750 respectively, in the first semester of 2008, had risen to CFAF 407 and CFAF 2,255, respectively, in 2012, corresponding to a $20 \%$ and $24 \%$ increase (MINAGRI \& INS, 2011).

To assess the impact on household well-being of those price rises, the present study used the compensating variation of income. Table 11 provides the variations in well-being in monetary terms for all the regions of Côte d'Ivoire.

Table 11: Monetary assessment of the loss in household well-being in Côte d'Ivoire

Compensating variation (in CFAF)

\begin{tabular}{|c|c|c|c|c|c|c|}
\hline & Nationally & $\begin{array}{l}\text { Northern } \\
\text { region }\end{array}$ & $\begin{array}{l}\text { Eastern } \\
\text { region }\end{array}$ & $\begin{array}{l}\text { Central } \\
\text { region }\end{array}$ & $\begin{array}{l}\text { Western } \\
\text { region }\end{array}$ & $\begin{array}{l}\text { Southern } \\
\text { region }\end{array}$ \\
\hline $20 \%$ price increase for rice & 2,912 & 30,038 & 21,006 & 22,573 & 26,149 & $\mathbf{3 5 , 5 5 7}$ \\
\hline $\begin{array}{l}\text { Share of rice in food } \\
\text { expenditures (in \%) }\end{array}$ & 11.75 & 12.23 & 10.749 & 11.689 & 12.066 & 12.68 \\
\hline $24 \%$ price increase for meat & $\mathbf{5 0 , 8 3 6}$ & 42,091 & 40,339 & 50,552 & 50,263 & 50,958 \\
\hline $\begin{array}{l}\text { Share of meat in food } \\
\text { expenditures (in \%) }\end{array}$ & 9.55 & 9.37 & 7.6 & 10.79 & 9.67 & 10.95 \\
\hline
\end{tabular}

The $20 \%$ rise in the price of rice led to an average loss in well-being of about CFAF 32,912 per household per year. A similar rise in the price of meat led to an average loss in well-being of CFAF 50,838 per household per year. However, the levels of loss in well-being varied from one region to another. In fact, they were found to be higher for the regions where the relative shares of the food budget allocated to rice and meat were the highest.

\section{Discussion of the Results}

The present study's results of the estimations of the budget shares allocated to the different foodstuffs show that regional differences, income and prices are explanatory factors for the observed variations in household food expenditures. The positive signs for the expenditure 
elasticities and the negative signs for the direct price elasticities of the estimated equations are consistent with economic theory.

The effects of complementarity and substitution were highlighted by the cross price elasticities. Indeed, the positive signs for cross price elasticities between root crops, tubers and cereals are an indication of net substitution between these three types of foods. In particular, cassava and yam were found to be substitutes for rice. On the other hand, the negative and significant signs for the estimated cross price elasticities mean that vegetables and animal products are two food clusters that were found to be complementary to each other and also complementary to starchy foods.

These substitution and complementarity relationships are a reflection of eating habits marked by the agro-natural characteristics of the different regions, the area of residence (urban vs. rural), and the households' sociocultural origin. It is indeed a fact that food patterns in Côte d'Ivoire comprise an essential staple food (such as rice, yam, cassava, or plantain) and a variety of soups ${ }^{1}$ made of vegetables and animal products.

The composition of these vegetable soups (made of eggplants, okra, tomatoes, onions, etc.), which are served with animal products (meat and fish), illustrates the complementarity between the vegetables and the animal products clusters. Moreover, cereals, root crops, tubers and plantain comprise the bulk of accompaniments for soups made of vegetables and animal products. Such eating habits will explain the complementarity relationships established between starchy foods, animal products and vegetables.

Still in relation to the agro-natural characteristics and sociocultural origins, the relative weights for staple accompaniments (rice, maize, yam, cassava and plantain) in the households' diet differed from one region to the next: rice was found to be the dominant staple food in the north-west and the west of Côte d'Ivoire, tubers in the centre, the centre-east and the south-east, plantain and cassava in the south, and cereals and yam in the north. In the regions where rice was not the traditional staple food, the non-cereal starchy foods (cassava, yam and plantain) constituted the natural substitutes for rice.

Consumption of processed foods produced by the cottage industry (such as attiéké, cassava flour, plantain flour, yam and plantain fries, doughnuts, etc.) is an important part of the urban diet in Côte d'Ivoire. Conservation and processing techniques in the urban areas enable the non-cereal food crops (cassava, yam, and plantain) to be substitutes for rice for long periods of the year.

\section{Conclusion and Economic Policy Implications}

The present study analyzed the demand for staple foods in Côte d'Ivoire and measured the effects of price fluctuations on household well-being in the country. A quadratic almost ideal demand system (QUAIDS) model was estimated in order to highlight the price and expenditure elasticities of the demand for staple foods. The relationships between food expenditure shares, prices, food budget and household sociodemographic characteristics were

\footnotetext{
${ }^{1}$ A soup made of crushed vegetables
} 
measured quantitatively.

The results show that regional variables were pertinent explanatory factors for the observed variations in household food expenditures. This means that implementing an effective food security policy in the country will require that greater attention should be paid to regional differences in the food expenditure structure.

All the expenditure elasticities were found to be positive and lower than 1, with the exception of those for animal products for the low-income households. For this income group, animal products were identified as luxury goods, the demand for which was strongly sensitive to income variations. Further, the demand for animal products was found to be elastic for the low-income households. The implication of this observation is that these households will react by significantly increasing their demand for animal products each time there is a substantial drop in prices.

The present study's estimations of the price elasticities are consistent with the economic literature that characterizes the demand for food products as inelastic. Indeed, with the exception of animal products for the low-income households, the direct price elasticities were all found to be negative and lower than 1 . On the whole, the food products studied showed a direct price elasticity and an expenditure elasticity that were significantly different from zero. The implication of this result is that the price policies currently being implemented should be accompanied by a policy focussed on income so as to achieve a greater effect on the promotion of food consumption.

Unlike other studies conducted on developing countries (Erhabor \& Ojogho, 2011; Weliwita et al., 2003), the present one did not find significant effects of substitution between rice and the other cereals in Côte d'Ivoire. This result can be partly attributed to the predominance of rice, the production of which represents more than half of the cereal production in the country. Moreover, rice has, at the expense of other cereals, monopolized the bulk of public investment destined for the promotion of food security (Hirsch, 1993). Such a deliberate policy in favour of rice has made it the main staple cereal in the country but has discouraged the promotion of other cereal substitutes.

On the other hand, cassava and yam were found to be substitutes for rice, as their cross price elasticities were found to be positive and significant. This stresses the need to fully integrate root crops and tubers into the food security policy so as to partially meet the structural deficit in rice.

Côte d'Ivoire's food supplies are principally of a vegetable origin, with more than $50 \%$ of it coming from rice, root crops and tubers (MINAGRI \& INS, 2011). The present study has established the complementarity effects that exist between food products of a vegetable origin (rice, root crops and tubers) and animal products. The implication of this is that food security policies must attach as much importance to animal products as to those of vegetable origin.

The 2008 food crisis considerably affected household well-being in Côte d'Ivoire. This led the government to take various measures (among which tax relief and a scheme to increase the production of food crops) aimed at mitigating the effects of price increases. However, 
because they were implemented only partially, the measures in question have not had a significant impact on household well-being (MINAGRI \& INS, 2011).

The present study has shown that the loss in well-being related to the food crisis and measured in monetary terms varied from one region to another. It is thus urgent to take measures to support the vulnerable households in order to consolidate their purchasing power. Such measures can be in the form of tax readjustment in favour of the vulnerable groups and a greater efficiency in marketing food products. Moreover, it would be beneficial if those measures were accompanied by a policy aimed at supporting the diversification of food crop production.

There is not much empirical research that has analyzed the food demand by income group in Côte d'Ivoire. The present study's originality lies in the fact that it has examined the impact of economic and socioeconomic variables on the demand for the main food products. However, the study has its own limitations, concerning the fact that it was not able to take into account the temporal variability in prices. Future research using a larger base of panel data would enable a validation of the estimated elasticities.

\section{Acknowledgements}

I wish to express my deep appreciation to African Economic Consortium (AERC) for the financial support to carry out this research. I am also grateful to the resource persons and members of AERC's thematic group A for various comments and suggestions that helped the evolution of this study from its inception to completion. I am indebted to the anonymous referees who reviewed the paper and provided comments and suggestions that helped in shaping and improving the overall quality of the paper. The findings made and opinions expressed in this paper are exclusively those of the author. The author is also solely responsible for content and any errors.

\section{References}

Abdulai, A. (2002). "Household demand for food in Switzerland. A Quadratic Almost Ideal Demand System”. Swiss Journal of Economics and Statistics, 138, 1-18.

Agbola, F. (2002). "Estimation of food demand patterns in South Africa based on a survey of households". Journal of Agricultural and Applied Economics, 35(3), 662-70.

Allais, O., Bertail, P., \& Nichèle, V. (2010). "The effect of a Fat Tax on French Households' Purchases: A Nutritional Approach", American Journal of Agricultural Economics, 92(1), 228-245. https://doi.org/10.1093/ajae/aap004

Allen, T. (2010). Impacts des variations de prix sur la qualité nutritionnelle du panier alimentaire des ménages français. $\mathrm{PhD}$ Thesis in Economics and Management, EDEC, University of Montpellier 1.

Atkinson, A., J. Gomulka, \& N. Stern, (1990). "Spending on alcohol: Evidence from the Family Expenditure Survey 1970-1983”. Economic Journal, 100, 808-27.

https://doi.org/10.2307/2233660 
Banks, J., R. Blundell, \& A. Lewbel, (1996). "Tax reform and welfare measurement: Do we need demand system estimation?" Economic Journal, 106, 1227-41.

https://doi.org/10.2307/2235517

Blundell, R. \& Robin, J. (2000). "Latent separability: Grouping goods without weak separability". Econometrica, 68, 53-84. https://doi.org/10.1111/1468-0262.00093

BNETD. (2010). Étude de faisabilité d'un plan national de développement des vivriers en Côte d'Ivoire; Atelier de réflexion et de validation des termes de référence d'un programme national de vivriers. Abidjan.

Bollino, C. (1990). "A generalized version of the Almost Ideal and Translog Demand System”. Economics Letters, 34, 127-9. https://doi.org/10.1016/0165-1765(90)90231-O

Bopape, L. (2006). The influence of demand model selection on household welfare estimates: An application to South African food expenditures. PhD Thesis in Agricultural Economics, Michigan State University.

Bopape, L., \& Myers, R. (2007). "Analysis of household demand for food in South Africa: Model selection, expenditure endogeneity, and the influence of sociodemographic effects". Paper presented at the African Econometrics Society Conference, Cape Town, South Africa, July $4-6$, (2007).

Camara, A., \& Dramane, B. (1992). Évaluation de la situation alimentaire nationale du point de vue de la sécurité alimentaire, et identification des problèmes à résoudre. FAO Working Document.

Carpentier, A., \& Guyomard, H. (2001). "Unconditional elasticities in two-stage demand systems: An approximate solution". American Journal of Agricultural Economics, 83(1), p. 222-229. https://doi.org/10.1111/0002-9092.00149

Christensen, L., Jorgensen, D., \& Lau, L. (1975). “Transcendental logarithmic utility functions". American Economic Review, 65, 367-83.

Cox, T., \& Wohlgenant, M. (1986). "Prices and quality effects in cross-sectional demand analysis". American Journal of Agricultural Economics, 68(4), 908-19. https://doi.org/10.2307/1242137

Deaton, A. (1997). The Analysis of Household Surveys: A Microeconometric Approach to Development Policy. Baltimore: Johns Hopkins University Press for the World Bank. https://doi.org/10.1596/0-8018-5254-4

Deaton, A., \& Muellbauer, J. (1980). "An Almost Ideal Demand System". American Economic Review, 70, 312-26.

Deaton, A., \& Tarozzi, A. (2000). "Prices and poverty in India". Research Program in Development Studies, Princeton University.

Denton, F., \& Mountain, D. (2004). "Aggregation effects on price and expenditure elasticity in a Quadratic Almost Ideal Demand System”. The Canadian Journal of Economics, 37, 
613-28. https://doi.org/10.1111/j.0008-4085.2004.00240.x

Dhar, T., \& Foltz, J. (2005). "Milk by any other name... Consumer benefits from labeled milk”. Food System Research Group Working Paper Series, FSWP2003 - 2.

Erhabor, P., \& Ojogho, O. (2011). "Demand Analysis for Rice in Nigeria". Journal of Food Technology, 9(2), 66-74. https://doi.org/10.3923/jftech.2011.66.74

Fao \& Wfp (2008), Evaluation approfondie de la sécurité alimentaire des ménages, Abidjan, $65 \mathrm{P}$.

Faostat. (2010). FAO Statistical database. FAOSTAT-Agriculture Data.

Fisher, D., Fleissig, A., \& Serletis, A. (2001). "An empirical comparison of flexible demand system functional forms". Journal of Applied Econometrics, 16(1), 59-80.

https://doi.org/10.1002/jae.585

Hausman, J. A., Newey, W. K., Powell, J. L. (1994). "Nonlinear errors-in-variables: Estimation of some Engel curves”. Journal of Econometrics 65, 205-233.

https://doi.org/10.1016/0304-4076(94)01602-V

Heckman, J. (1979). "Sample selection bias as a specification error". Econometrica, 47, 153-61. https://doi.org/10.2307/1912352

Henderson, J. M., \& Quandt, R. E. (1958). Microeconomic Theory: A Mathematical Approach. New York: McGraw-Hill.

Hirsch, R. (1993). Le riz et les politiques rizicoles en Côte d'Ivoire 1960-1993. Caisse Française de Développement, département des politiques et des études.

INS. (2008). Enquête sur le niveau et les conditions de vie des ménages. Survey conducted by the National Institute of Statistics.

Jones, A., \& Mazzi, M. (1996). "Tobacco consumption and taxation in Italy: An application of the QUAIDS model". Applied Economics, 28, 595-603.

https://doi.org/10.1080/00036849600000039

Karagiannis, G., \& Velentzas, K. (2004). "Decomposition analysis of consumers' demand changes: An application to Greek consumption data". Applied Economics, 36(5), 497-504.

https://doi.org/10.1080/00036840410001682205

Lewbel, A. (1991). "The rank of demand systems: Theory and non-parametric Estimation". Econometrica, 59, 711-30. https://doi.org/10.2307/2938225

Liebenberg, G., \& Groenewald, J. (1997). "Demand and supply elasticities of agricultural products: A comparison of South African estimates". Pretoria: Agricultural Research Council.

Lyssiotou, P. (2003). "On estimating the cost of characteristics indices from consumer demand analysis." Canadian Journal of Economics, 36, 326-49.

https://doi.org/10.1111/1540-5982.t01-1-00003 
Maillot, M., Darmon, N., Vieux, F., \& Drewnowski, A. (2007). "Low energy density and high nutritional quality are each associated with higher diet costs in French adults". American Journal of Clinical Nutrition, 89(4), 1227 - 36.

MINAGRI, \& INS. (2011). Rapport sur la dynamique de la consommation alimentaire en Côte d'Tvoire.

Molina, J., \& Gil, A. (2005). "The demand behavior of consumers in Peru: A demographic analysis using the QUAIDS”. Journal of Developing Areas, 39(1), 191-206.

https://doi.org/10.1353/jda.2005.0038

Moschini, G., Moro, D.m \& Green, R. (1994). "Maintaining and testing separability in demand systems". American Journal of Agricultural Economics, 76(1), 61-73.

https://doi.org/10.2307/1243921

Nayga, R., \& Capps, O. (1994). "Tests of weak separability in disaggregated meat products". American Journal of Agricultural Economics, 76(4), 800-8.

https://doi.org/10.2307/1243741

Nicol, C. (2003). "Elasticities of demand for gasoline in Canada and the United States". Energy Economics, 25, 201-14. https://doi.org/10.1016/S0140-9883(03)00002-1

Nieuwoudt, W. (1998). "The demand for livestock products in South Africa for 2000, 2010 and 2020: Part 1". Agrekon, 37(2), 130 - 142.

https://doi.org/10.1080/03031853.1998.9523500

Pomboza, R., \& Mbaga, M. (2007. "The estimation of food demand elasticities in Canada". Economic and Market Information, (Publication 06-071-RB).

Royston, J. P. (1983). "A simple method for evaluating the Shapiro-Francia W-test of non-normality". Journal of the Royal Statistical Society, 32(3), 297-300.

https://doi.org/10.2307/2987935

Senauer, B. (1990). "Household behaviour and nutrition in developing countries". Food Policy, vol 15(5), 408 - 417. https://doi.org/10.1016/0306-9192(90)90057-7

Senauer, B., \& Kinsey, J. (1991). Foods Trends and the Changing Consumer. CITY STATE: Eagan Press.

Stone, R. (1954). "Linear expenditure systems and demand analysis: An application to the pattern of British demand". Economic Journal, 64, 511-27. https://doi.org/10.2307/2227743

Taljaard, P., Alemu, Z., \& van Schalkwyk, D. (2004). "The demand for meat in South Africa: An almost ideal estimation." Agrekon, 43(4), 430-43.

Theil, H. (1976). Theory and Measurement of Consumer Demand. Amsterdam: North-Holland.

Timmer, C. (1981). "Is there curvate in the Slutsky Matrix?" Review of Economics and Statistics, 63, 395-402. https://doi.org/10.2307/1924357 


\section{Macrothink}

Journal of Agricultural Studies

ISSN 2166-0379

2017, Vol. 5, No. 4

Ulimwengu, J, Roberts, C., \& Randriamamonjy, J. (2012). Analysis of the Demand for Food Nutrients in the Democratic Republic of Congo. IFPRI Discussion Paper 01154.

Unayama, T. (2004). "Upward bias in the consumer price index under the zero-inflation economy". Economics, 34, 2053-61. https://doi.org/10.1080/03031853.2004.9523659

United Nations Millennium Project. (2005). Investing in Development: A Practical Plan to Achieve the Millennium Development Goals. New York: UN Millennium Project.

Urzùa, C. (2001). "Welfare consequences of a recent tax reform in Mexico". Estudios Economicos, 16(1), 57-72.

Weliwita, A., Nyange, D., \& Tsujii, H. (2003). "Food demand patterns in Tanzania: A censored regression analysis of microdata". Sri Lankan Journal of Agricultural Economics, $5(1), 9-34$.

Yao, N., Oulé, A., \& N'goran, K. (2013). Etude de vulnérabilité du secteur agricole face aux changements climatiques en Côte d'Ivoire, Rapport PNUD.

\section{Copyright Disclaimer}

Copyright for this article is retained by the author(s), with first publication rights granted to the journal.

This is an open-access article distributed under the terms and conditions of the Creative Commons Attribution license (http://creativecommons.org/licenses/by/4.0/). 